\title{
Comorbidities, repeated hospitalizations, and age $\geq 80$ years as indicators of anemia development in the older population
}

\author{
Sylwia Sulimiera Michalak ${ }^{1,2} \cdot$ Joanna Rupa-Matysek $^{2}$ (D) $\cdot$ Lidia Gil $^{2}$ \\ Received: 8 November 2017 / Accepted: 30 March 2018 /Published online: 9 April 2018 \\ (C) The Author(s) 2018
}

\begin{abstract}
Anemia represents a common condition among the elderly; however, its prevalence and causes are not well known. This retrospective analysis was performed on 981 patients aged $\geq 60$ in Poland over 2013-2014. The prevalence of anemia was $17.2 \%$ and increased with age. The predominant causes of anemia were the following: anemia of chronic disease (33.1\%), unexplained anemia (28.4\%), deficiency anemia (22.5\%, including iron deficiency $13 \%)$, and chemo-/radiotherapy-induced anemia (8.9\%). In the multivariate logistic regression model, factors increasing the risk of anemia were the following: age $\geq$ 80 years (OR 2.29; 95\% CI 1.19-4.42; $P=0.013$ ), the number of comorbidities (two diseases OR 2.85; 95\%CI 1.12-7.30; $P=$ 0.029 , three diseases OR 6.28; 95\%CI 2.22-17.76; $P=0.001$, four diseases OR 4.64; 95\%CI 1.27-17.01; $P=0.021$ ), and hospitalizations (OR 1.34; 95\%CI 1.13-1.58; $P=0.001)$. After a 2-year follow-up, the cumulative survival among patients without anemia in relation to the group with anemia was 90.76 vs. $78.08 \%(P<0.001)$. In the multivariate model, anemia (HR 3.33, 95\% CI 1.43-7.74, $P=0.005$ ), heart failure (HR 2.94, 95\% CI 1.33-6.50, $P=0.008$ ), and cancer (HR 3.31, 95\%CI $1.47-7.49, P<0.004)$ were all significantly correlated with mortality. In patients $\geq 60$ years, the incidence of anemia increases with age, number of comorbidities, and frequency of hospitalizations and has an adverse impact on survival.
\end{abstract}

Keywords Anemia $\cdot$ Elderly $\cdot$ Comorbidities $\cdot$ Risk factor $\cdot$ Survival

\section{Introduction}

The population of people older than 60 years is increasing by $3.26 \%$ annually, and it has been estimated that by 2050 , it will constitute $25 \%$ of the entire population [1]. High frequency of comorbidities, polypharmacotherapy, and hospitalization is commonly seen in this group of people [2-4]. Anemia is a common condition among the elderly and is increasing with age. The etiology of anemia in the elderly is often complex, and only a few studies have been performed to evaluate the impact of multiple factors, including comorbidities and hospitalizations, on the development of anemia [5-7].

Joanna Rupa-Matysek

rupa.matysek@gmail.com

1 Faculty of Medicine and Health Sciences, University of Zielona Góra, Zielona Góra, Poland

2 Department of Hematology and Bone Marrow Transplantation, Poznan University of Medical Sciences, Szamarzewskiego 84, 60-569, Poznań, Poland
The aim of the study was to evaluate the prevalence, severity, and etiology of anemia with a risk factor analysis for its development in the population aged $\geq 60$ years, with respect to comorbidities and hospitalizations.

\section{Materials and methods}

Retrospective analysis was performed on all consecutive white patients aged 60 years or over, who were under the care of a specific primary medical care clinic in Poland during 2013-2014. Primary medical clinic provided only ambulatory, outpatient care. In the case of hospitalization, the patient stayed under the care of a hospital specialist and after discharge returned to the primary medical care clinic. All patients' data, including the level of hemoglobin and types of anemia, common comorbidities, and hospitalizations were derived from the medical records of the clinic and patient's files. Data on all-cause mortality between the first of January 2013 and the 31st of December 2014 were based on the reports of the National Health Fund. 
Table 1 The definitions of the different types of anemia, adapted based on published data [12, 15-17]

\begin{tabular}{|c|c|c|}
\hline Anemia etiology & Criteria & Comments \\
\hline Iron deficiency & Serum ferritin $<30 \mathrm{ng} / \mathrm{ml}, \mathrm{TfS}<16 \%$ & $\begin{array}{l}\text { Excluded if not corrected by } 2 \text { months of oral or intravenous iron } \\
\text { therapy }\end{array}$ \\
\hline Vitamin B12 deficiency & Vitamin $\mathrm{B} 12<197 \mathrm{pg} / \mathrm{ml}$ & Excluded if not corrected by 3 months of vit. B12 therapy \\
\hline Folate deficiency & Folate level < lower limit of normal & Excluded if not corrected by 3 months of folate therapy \\
\hline Anemia of chronic disease & $\begin{array}{l}\text { Elevations of CRP, ESR, serum ferritin } \\
>100 \mathrm{ng} / \mathrm{ml} \\
\text { The presence of chronic or acute infection; } \\
\text { autoimmune diseases (systemic lupus } \\
\text { erythematosus, rheumatoid arthritis, } \\
\text { inflammatory bowel disease) }\end{array}$ & $\begin{array}{l}\text { Elevations of CRP, ESR, serum ferritin } 30-100 \mathrm{ng} / \mathrm{ml} \text {, } \\
\text { considered as coexistence of iron deficiency but was } \\
\text { eligible for ACD }\end{array}$ \\
\hline Renal insufficiency anemia & $\mathrm{eGFR}<30 \mathrm{ml} / \mathrm{m}^{2} / \mathrm{min} / 1.73 \mathrm{~m}^{2}$ & Normal values of CRP and ESR \\
\hline $\begin{array}{l}\text { Chemo- and/or radiotherapy-induced } \\
\text { anemia }\end{array}$ & $\begin{array}{l}\text { Confirmed cause-and-effect relationship } \\
\text { with } \\
\text { chemo-/radiotherapy }\end{array}$ & $\begin{array}{l}\text { Anemia occurred during oncological treatment and lasted at } \\
\text { least } 1 \text { month after treatment }\end{array}$ \\
\hline Anemia in the course of thyroid disease & $\mathrm{TSH}<0.1 \mathrm{mU} / 1$ or $>10 \mathrm{mU} / 1$ & Regression of anemia after normalization of thyroid dysfunction \\
\hline Hemorrhagic anemia & $\begin{array}{l}\text { The presence of overt bleeding with drop } \\
\text { in } \\
\text { hemoglobin level }\end{array}$ & \\
\hline $\begin{array}{l}\text { Anemia in the course of chronic liver } \\
\text { disease }\end{array}$ & $\begin{array}{l}\text { The presence of chronic liver disease: } \\
\text { cirrhosis, } \\
\text { chronic viral hepatitis }\end{array}$ & Other causes of anemia excluded \\
\hline Alcohol-induced anemia & The presence of alcoholic illness & Other causes of anemia excluded \\
\hline
\end{tabular}

$C R P, \mathrm{C}$ reactive protein; $E S R$, erythrocyte sedimentation rate; TfS, transferrin saturation; $e G F R$, estimated Glomerular filtration rate; $T S H$, thyrotropin; $A C D$ anemia of chronic disease

Both, patients aged $\geq 60$ years with anemia detected in the years 2013-2014 and patients with anemia diagnosed earlier (since 2001) but aged 60 or over at the time of diagnosis, were included in the study. The incidence of anemia, comorbidities, and hospitalizations since the age of 60 were analyzed both in the entire population and also separately in the patients with and without anemia.

\section{Definitions of anemia and types of anemia}

Anemia was defined as hemoglobin levels lower than $12 \mathrm{~g} / \mathrm{dl}$ in women and $13 \mathrm{~g} / \mathrm{dl}$ in men according to WHO criteria [8]. If a single morphological result with a reduced hemoglobin concentration was found in the medical records, which was not confirmed in subsequent studies and without clinical data indicating anemia, no anemia was diagnosed. Finding the presence of anemia at the age of 60 and over resulted in the patient being classified with anemia. In anemic patients, the result of morphology at the time of diagnosis of anemia was analyzed, and in patients without anemia, the last morphology result performed in the years 2012-2014. The severity of anemia was established according to the most commonly used classification subtypes: mild anemia: $10-12 \mathrm{~g} / \mathrm{dl}$ in woman and 10$13 \mathrm{~g} / \mathrm{dl}$ in men, moderate anemia $8-9.9 \mathrm{~g} / \mathrm{dl}$, severe anemia $6.5-7.9 \mathrm{~g} / \mathrm{dl}$, and very severe anemia under $6.5 \mathrm{~g} / \mathrm{dl}$ [9]. The severity of anemia was established based on the hemoglobin concentration at the time of diagnosis.

The following types of anemia were determined: deficiency anemia's (iron deficiency, vitamin B12 deficiency, folate acid deficiency, and complex deficiency anemia), hemorrhagic anemia, anemia of chronic disease, renal insufficiency anemia, chemo- and/or radiotherapy-induced anemia, and other types in the course of chronic liver disease, alcoholic disease, thyroid gland disease, and unexplained anemia. The definitions of each types of anemia are listed in Table 1. If a patient underwent chemo- or radiotherapy and had anemia lasting at least a month and there was a cause-and-effect relationship between the onset of anemia and cancer therapy, we classified the patient as chemo- and/or radiotherapy-induced anemia. The cause-and-effect relationship was defined as follows: before cancer therapy, there was no anemia nor any other risk factors (e.g., bleeding, inflammation markers indicative of another cause of anemia), anemia occurred during oncological treatment and lasted at least 1 month after treatment. GFR $<$ $30 \mathrm{ml} / \mathrm{min} / 1.73 \mathrm{~m}^{2}$ was considered a criterion for diagnosing anemia in the course of kidney disease [10-14].

Anemia was defined as unexplained if, based on available patients' records and laboratory tests, no other types of anemia were identified.

The factors that increase the likelihood of anemia were examined using the logistic regression model. The probability 
is expressed by the odds ratio (OR). The following variables were analyzed: gender, age, renal function (determined on the basis of eGFR), selected comorbidities (coronary heart disease, diabetes, insulin-dependent diabetes, chronic kidney disease, heart failure, chronic obstructive pulmonary disease, thyroid diseases, cancer, and chronic liver diseases), number of comorbidities, number of hospitalizations, and selected drugs (anticoagulants and aspirin).

\section{Demographic variables, comorbidities, hospitalizations, and procedures}

Based on medical records, data on age (divided into groups $60-69,70-79, \geq 80$ ), gender, hemoglobin concentration, and type of anemia was collected. Data on the incidence of common comorbidities including hypertension, coronary heart disease/cardiovascular disease, heart failure, atrial fibrillation, venous thromboembolism, diabetes including diseases with chronic complications (macroangiopathy, microangiopathy, neuropathy, and retinopathy), chronic lung disease including asthma and chronic obstructive pulmonary disease, chronic kidney disease, cancer, hematological malignancies, chronic liver diseases, rheumatic disease, and thyroid diseases were obtained. All comorbidities were diagnosed according to the most current guidelines of the relevant international societies [15-25], and results from specialist consultations and hospital discharge cards. Heart failure was diagnosed on the basis of subjective and objective symptoms as well as features of systolic or diastolic heart dysfunction in echocardiography [15]. Cancer was defined as malignant neoplasm, confirmed by histopathology, imaging and laboratory tests [25], and required treatment (active cancer). Melanoma and other skin cancers were also evaluated in the study. The appropriate treatment recorded in the documentation confirmed the diagnosis of specific diseases. The data on the use of prophylactic aspirin (75-150 mg), clopidogrel, vitamin $\mathrm{K}$ antagonists (VKA), and DOACs (Direct Oral Anticoagulants) were also collected.

The incidence of hospitalizations, excluding hospitalization for surgery, rehabilitation, and cancer treatment was also analyzed. In the course of hospitalization, the incidence of coronary angiography and percutaneous transluminal coronary angioplasty (PTCA) was assessed in patients with and without anemia.

The Bioethical Committee of Poznan University of Medical Sciences approved the study.

\section{Statistical analysis}

The results are presented using methods of descriptive statistics such as the frequency $(n)$, mean/medians, standard error (SE), and range. The Shapiro-Wilk test was performed to assess normality. To compare differences between the groups, the chi-squared test or the Fisher-Freeman-Halton exact test was used for categorical variables and the Mann-Whitney $U$ test for continuous variables. The differences in the proportions between the groups (anemia/no anemia) were compared using the test for proportions.

Univariate logistic regression was used to evaluate potential risk factors for a higher prevalence of anemia. A multivariate analysis was performed with selected variables that were significant in the univariate analysis. In each model, the OR for each independent variable was determined with a confidence interval (CI) of $95 \%$.

The probabilities of survival were estimated via the Kaplan-Meier method, and univariate comparisons were performed using the log-rank test. The Cox proportional hazards model was fitted to estimate the effect of the analyzed factors on the mortality. In this model, the hazard ratio (HR) for each independent variable was determined with a $\mathrm{CI}$ of $95 \%$. A $P$ value below 0.05 was regarded as statistically significant.

The statistical analyses were performed with STATISTICA 10 and STATISTICA Medical Package 2.0 (Stat Soft, Inc. 2012 software, Tulsa, USA).

\section{Results}

Of 3500 patients under the care of one primary medical care clinic, 1152 were 60 years old or older, of this group 981 patients were included into the study (Fig. 1). Detailed data concerning the demographic characteristics of the studied population is shown in Table 2.

In the analyzed population, the mean hemoglobin concentration in women was lower than in men (13.15 vs. $13.95 \mathrm{~g} / \mathrm{dl}$; $P<0.001)$. Anemia was found in 169 patients $(17.2 \%)$, including 90 women $(9.2 \%)$ and 79 men (8.0\%). The prevalence of anemia was higher in men than women (20.4 vs. 15.2\%; $P=0.038)$. Anemia incidence increased statistically significantly with age groups $(60-69$ vs. $70-79 P<0.001,60-69$ vs. 80 or more $P<0.001,70-79$ vs. 80 or more $P<0.001$ ) (Table 3).

The anemia was mild in 118 patients $(69.8 \%)$, moderate in 40 patients $(23.7 \%)$, severe in 6 patients $(3.6 \%)$, and very severe in 5 patients (3.0\%). The group of men aged 80 or over was more likely to have severe anemia than younger ones $(P=0.030)$.

\section{Types of anemia}

The predominant causes of anemia were the following: anemia of chronic disease (33.1\%), unexplained anemia (28.4\%), and deficiency anemia $(22.5 \%$, including iron deficiency constituting $13 \%$ of all cases), and $8.9 \%$ of anemia resulted from cancer treatment (chemo-/radiotherapy-induced anemia). The incidence of other types of anemia in the studied population is 
Fig. 1 Patients in the study. *The exclusions concerned patients who were not consulted in the primary medical care clinic in 2013-2014 or who did not undergo basic laboratory tests

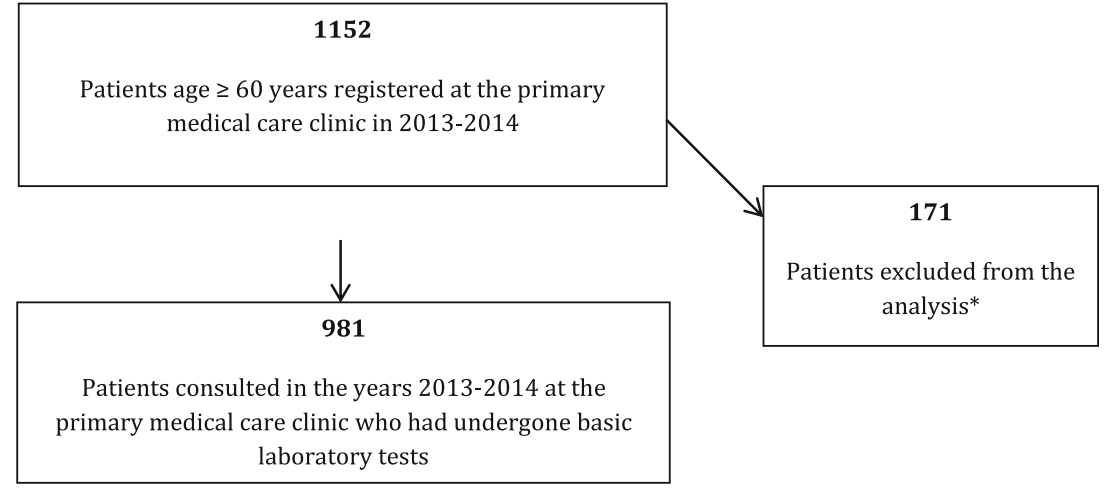

presented in Fig 2. No case of aplastic anemia or hemolytic anemia was diagnosed during observation.

The analysis of the prevalence of anemia in different age groups showed a more significant increase in the incidence of anemia of chronic disease (ACD) in the 60- to 69-year group than in the 70 - to 79 -year group ( 21.4 vs. $41.8 \%, P=0.021$ ). Similarly, the incidence of chemo-/radiotherapy-induced anemia in the 60- to 69-year group was higher compared to the 70 - to 79 -year group ( 19.6 vs. $5.5 \%, P=0.024)$ and the $\geq 80$ group (19.6 vs. $1.7 \% P=0.002)$.

\section{Association of anemia with age, comorbidities, and hospitalization}

In comparison to the patients without anemia, those with anemia were older (median age 75 vs. $67, P<0.001$ ), had a higher prevalence of comorbidities (median 3 vs. $2, P<0.001$ ), and statistically significantly more often had cardiac complications, venous thromboembolism, diabetes including diseases with chronic complications, chronic obstructive pulmonary disease, thyroid diseases, chronic kidney disease, cancer, chronic liver diseases, or rheumatic disease. The detailed clinical characteristics of the patients with or without anemia are provided in Table 4.

The analysis of the prevalence of comorbidities in the age groups 60-69, 70-79, and $\geq 80$ showed that heart failure was significantly more common in patients with anemia $(P=$ $0.002, P=0.018$, and $P=0.013$, respectively), chronic kidney disease $(P=0.013, P<0.001, P=0.013$, respectively), and chronic liver disease $(P<0.001, P=0.013, P=0.007$,

Table 2 Demographic characteristics of studied population

\begin{tabular}{ll}
\hline Characteristic & Result \\
\hline Total population, $n$ & 981 \\
Median age (range), years & $68(60-99)$ \\
$60-69$ years, $n(\%)$ & $544(55.5)$ \\
$70-79$ years, $n(\%)$ & $274(27.9)$ \\
$\geq 80$ years, $n(\%)$ & $163(16.6)$ \\
Gender: female $/$ male $n(\%)$ & $594(60.6) / 387(39.4)$ \\
\hline
\end{tabular}

respectively). Patients with anemia were more often hospitalized (median 2 vs. $0, P<0.001$ ) and more often had coronary angiography and/or PTCA than those without anemia $(P<0.001)$.

\section{Risk factors for the anemia development}

From the risk factors analyzed for the development of anemia (age, gender, kidney function based on eGFR, comorbidities, and hospitalizations), most of them were statistically significant based on the univariate logistic regression model (Table 5). In the multivariate logistic regression model, age $\geq$ 80 years (OR 2.29; 95\% CI 1.19-4.42; $P=0.013$ ), the number of comorbidities (two diseases OR 2.85; 95\% CI 1.11-7.29; $P=0.029$, three diseases (OR 6.28; 95\%CI 2.22-17.76; $P=$ 0.001 ), four diseases OR 4.64; $95 \%$ CI $1.26-17.00 ; P=$ 0.021 ), and number of hospitalizations (OR $1.34 ; 95 \% \mathrm{CI}$ $1.13-1.58 ; P=0.001)$ were all significantly associated with a higher prevalence of anemia (Table 6).

\section{All-cause mortality}

Of the 981 patients, 40 patients died (4.1\%) during the 2-year follow-up, including 21 (12.4\%) patients with anemia and 19 $(2.34 \%)$ in the group without anemia.

After a 1-year follow-up, the cumulative survival among patients with anemia in relation to the group without anemia was 87.63 vs. $97.54 \%$ and at the end of the study $78.08 \%$ (SE $\pm 0.055)$ and $90.76 \%$ (SE \pm 0.049$)$ respectively, and the difference was statistically significant $(P<0.001)$, Fig 3 .

To determine factors influencing survival, the variables including age, gender, selected comorbidities, hospitalizations, and also the presence and types of anemia were analyzed. In the univariate analysis, factors that significantly increased the risk of death were the following: age $\geq 80$ years (HR 7.6, 95\%CI 3.47-16.65, $P<0.001$ ), anemia (HR 4.32; 95\%CI 2.18-8.56, $P<0.001$, heart failure (HR 5.01, 95\%CI 2.569.80, $P<0.001$ ), and cancer (HR 4.82, 95\%CI 2.44-9.54, $P<0.001$ ) (Table 7). 
Table 3 Prevalence of anemia according to age groups (60-69, 70-79, 80 and over) and gender

\begin{tabular}{lllllll}
\hline Patients with anemia & $60-69$ years & $70-79$ years & $\geq 80$ years & \multicolumn{2}{l}{$P$ value } & \\
\cline { 5 - 7 } & $n(\%)$ & & & $60-69$ vs. $70-79$ & $60-69$ vs. $\geq 80$ & $70-79$ vs. $\geq 80$ \\
\hline Total & $56(10.3)$ & $55(20.1)$ & $58(35.6)$ & $<0.001$ & $<0.001$ & $<0.001$ \\
Women & $21(6.9)$ & $31(18.0)$ & $38(32.8)$ & $<0.001$ & $<0.001$ & $<0.001$ \\
Men & $35(14.7)$ & $24(23.5)$ & $20(42.6)$ & 0.225 & 0.015 & 0.238 \\
\hline
\end{tabular}

$P<0.05$ - statistically significant

In the multivariate model for the whole studied population, three factors including anemia (HR 3.33; 95\% CI 1.43-7.74; $P=0.005$ ), cancer (HR 3.31; 95\%CI 1.47-7.49; $P=0.004)$, and heart failure (HR 2.94; 95\%CI 1.33-6.50; $P=0.008$ ) all significantly correlated with the risk of mortality (Table 8 ).

\section{Discussion}

In the studied population aged 60 years or over, anemia as defined according to WHO criteria was found in $17.2 \%$ of patients, including $9.2 \%$ of women and $8.0 \%$ of men. Our results are in line with the observations of other authors concerning the prevalence of anemia in the elderly: $9.6 \%$ in the USA [26], $14.2 \%$ in Italian population [27], $17.4 \%$ in Poland [28], $13.6 \%$ in the Korean population [29], and $21 \%$ among Austrian people [30]. Based on the meta-analysis of patients aged 60 or over, it was estimated that the prevalence of anemia in men ranges from 2.9 to $61 \%$, while in women from 3.3 to $41 \%$ [31].

Consistent with literature on the elderly population [10, 32, 33], our data show that three types of anemia were predominant: ACD (33.1\%), unexplained anemia (28.4\%), and deficiency anemia $(22.5 \%)$ with iron deficiency reaching $13 \%$ of all anemia cases. The high prevalence of unexplained anemia needs attention - it has been reported by many authors, as affecting 16-40\% of elderly patients with anemia $[10,12,30,32,34]$. It is believed that some unexplained anemia cases are actually undiagnosed myelodysplastic syndrome (MDS), especially because the probability of MDS increases with age and initially, apart from anemia, there may be no other hematological abnormalities. Based on previous reports, MDS occurs in 5 to $15 \%$ of patients with anemia [10, 30, 32, 35], but other hematological malignancies may also be the case [12]. The high rate of unexplained anemia indicates the necessity for detailed hematologic diagnostics and also further research on anemia in the elderly. The development and greater availability of molecular tests may hopefully improve the diagnosis of unexplained anemia and other cytopenia. The presence of two or more somatic mutations in the genes (mutations that repeat in hematological malignancies) is associated with a higher probability of developing clonal disease [36]. Unfortunately, for the time being, these methods do not provide an answer, in a large percentage of patients, as to the cause of the anemia.

Our data revealed a significant proportion $(8.9 \%)$ of anemia associated with cancer treatment (chemo-/radiotherapyinduced anemia). This is also an important issue, because anemia is an independent risk factor for cancer mortality [37], and its successful treatment improves the quality of life and outcomes of cancer patients [38]. It has been shown in our study that anemia associated with cancer therapy is more likely to occur at 60-69 years of age compared to 70-79 years and
Fig. 2 Types of anemia in the studied population aged $\geq$ 60 years. *Other types of anemia included the following: anemia in the course of chronic liver disease $(n=2)$ and alcohol induced anemia $(n=1)$

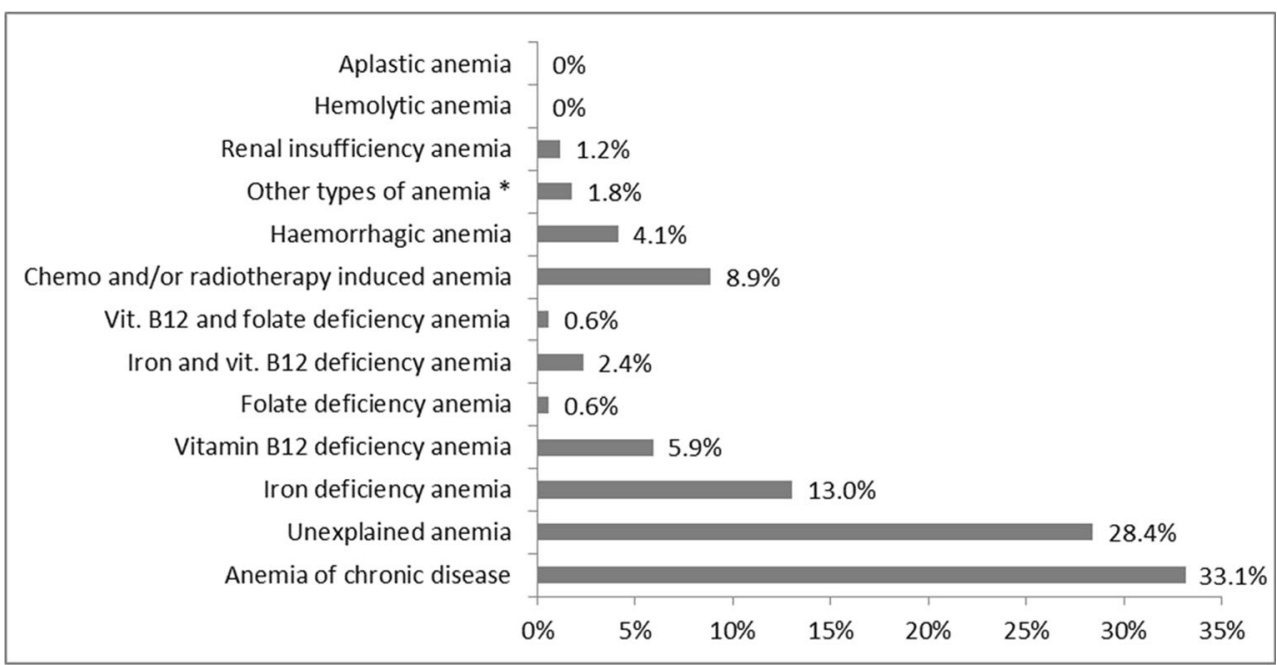


Table 4 Clinical characteristics of the patients with or without anemia

\begin{tabular}{|c|c|c|c|c|}
\hline Characteristics & $\begin{array}{l}\text { Total population } \\
n=981\end{array}$ & $\begin{array}{l}\text { Patients with anemia } \\
n=169\end{array}$ & $\begin{array}{l}\text { Patients without anemia } \\
n=812\end{array}$ & $P$ value \\
\hline Median age, years & 68 & 75 & 67 & $<0.001$ \\
\hline $\begin{array}{l}\text { Number of comorbidities, } \\
\text { median (range) } \\
\text { Comorbidities, } n(\%)\end{array}$ & $2(0-12)$ & $3(0-9)$ & $2(0-8)$ & $<0.001$ \\
\hline Hypertension & $772(78.7)$ & $146(86.4)$ & $626(77.1)$ & 0.007 \\
\hline Coronary heart disease & $319(32.5)$ & $76(45.0)$ & $243(29.9)$ & $<0.001$ \\
\hline Heart failure & $106(10.8)$ & $43(25.4)$ & $63(7.8)$ & $<0.001$ \\
\hline Atrial fibrillation & $102(10.4)$ & $35(20.7)$ & $67(8.3)$ & $<0.001$ \\
\hline Venous thromboembolism & $34(3.5)$ & $14(8.3)$ & $24(3.0)$ & 0.001 \\
\hline Diabetes & $245(25.0)$ & $53(31.4)$ & $192(23.6)$ & 0.035 \\
\hline Diabetes with complications & 143(14.6) & $40(23.7)$ & $103(12.7)$ & $<0.001$ \\
\hline Thyroid diseases & $182(18.6)$ & $42(24.9)$ & $140(17.2)$ & 0.021 \\
\hline Pulmonary disease & $118(12.0)$ & $34(20.1)$ & $84(10.3)$ & $<0.001$ \\
\hline Asthma & $51(5.2)$ & $8(4.7)$ & $43(5.3)$ & 0.765 \\
\hline COPD & $39(4.0)$ & $12(7.1)$ & $27(3.3)$ & 0.022 \\
\hline Chronic kidney disease & $102(10.4)$ & $49(29.0)$ & $53(6.5)$ & $<0.001$ \\
\hline Cancer & $101(10.3)$ & $44(26.0)$ & $57(7.0)$ & $<0.001$ \\
\hline Hematological malignancies & $7(0.7)$ & $6(3.6)$ & $1(0.1)$ & $<0.001$ \\
\hline Chronic liver diseases & $33(3.4)$ & $19(11.2)$ & $14(1.7)$ & $<0.001$ \\
\hline Rheumatic diseases & $11(1.1)$ & $7(4.1)$ & $4(0.5)$ & $<0.001$ \\
\hline \multicolumn{5}{|l|}{ Drugs, $n(\%)$} \\
\hline Aspirin & $259(26.4)$ & $82(48.5)$ & $177(21.8)$ & $<0.001$ \\
\hline Clopidogrel & $68(6.9)$ & $27(15.9)$ & $41(5)$ & $<0.001$ \\
\hline VKA & $78(8)$ & $30(17.8)$ & $48(5.9)$ & $<0.001$ \\
\hline DOACs & $25(2.5)$ & $10(5.9)$ & $15(1.8)$ & 0.002 \\
\hline Number of hospitalizations, median (range) & $0(0-12)$ & $2(0-12)$ & $0(0-11)$ & $<0.001$ \\
\hline Coronary angiography, $n(\%)$ & $140(14.3)$ & $53(31.4)$ & $87(10.7)$ & $<0.001$ \\
\hline PTCA, $n(\%)$ & $84(8.6)$ & $35(20.7)$ & $49(6.0)$ & $<0.001$ \\
\hline
\end{tabular}

$C O P D$, chronic obstructive pulmonary disease; $V K A$, vitamin $\mathrm{K}$ antagonists; $D O A C s$ direct oral anticoagulants; PTCA percutaneous transluminal coronary angioplasty

$P<0.05$ - statistically significant

80 years or more, which seems surprising, since the incidence of cancer increases with age, as well as the likelihood of anemia in the course of cancer and its treatment [39, 40].

The prevalence of anemia of chronic disease in our analysis was more common in the 70- to 79-year group than in the age group of 60 to 69 , which is supported by observations of the increased incidence with age disorders associated with increased proinflammatory activity [41]. The prevalence of other types of anemia in subsequent age groups (60-69 years, 70-79 years, and 80 years and over) was similar.

Patients with anemia were older, had a higher prevalence of comorbidities, more often used antiplatelet agents and oral anticoagulants, and were more often hospitalized. On the other hand, in the multivariate model, the increased number of comorbidities ( 2 to 4 ) significantly increased the risk of anemia development in the studied population. Comorbidities were more frequently found in patients with anemia, which has been also observed in other studies [5, 10, 42, 43]. Although a lot of research indicates the association between anemia and heart failure and chronic kidney disease, the link between anemia and chronic liver disease has not been highlighted. In the present study, a higher incidence of anemia in patients with chronic liver disease was demonstrated. The pathogenesis of anemia in the course of chronic liver disease is complex and is associated with acute and chronic gastrointestinal blood loss due to esophageal varices and portal gastropathy, folate deficiency, hipersplenism, direct toxicity due to alcohol, anemia of chronic disease, hemolysis, and hemostatic abnormalities in liver failure. In cirrhosis, especially that caused by alcohol abuse, folate deficiency, and vitamin B12 deficiency may be found [44]. Anemia in the course of chronic liver disease is an example of a phenomenon often seen in elderly patients, a common etiology of anemia but with a complex pathogenesis comprising various types of anemia. Similarly, 
Table 5 Univariate regression analysis for occurrence of anemia

\begin{tabular}{|c|c|c|c|}
\hline Parameter & OR & $95 \% \mathrm{CI}$ & $\mathrm{P}$ value \\
\hline Sex (male) & 1.44 & $1.03-2.01$ & 0.033 \\
\hline \multicolumn{4}{|l|}{ Age, year } \\
\hline $70-79$ & 2.19 & $1.46-3.28$ & $<0.001$ \\
\hline$\geq 80$ & 4.81 & $3.15-7.35$ & $<0.001$ \\
\hline \multicolumn{4}{|l|}{ eGFR $\left(\mathrm{ml} / \mathrm{min} / 1.73 \mathrm{~m}^{2}\right)$} \\
\hline$<15$ & 1.00 & - & - \\
\hline $15-29$ & 7.85 & $2.01-30.61$ & 0.003 \\
\hline $30-59$ & 3.44 & $2.08-5.68$ & $<0.001$ \\
\hline $60-89$ & 0.99 & $0.64-1.55$ & 0.969 \\
\hline Coronary heart disease & 1.91 & $1.36-2.68$ & $<0.001$ \\
\hline Diabetes & 1.48 & $1.03-2.12$ & 0.036 \\
\hline Insulin-treated diabetes & 2.67 & $1.53-4.65$ & 0.001 \\
\hline Chronic kidney disease & 5.99 & $3.85-9.32$ & $<0.001$ \\
\hline Heart failure & 4.06 & $2.64-6.24$ & $<0.001$ \\
\hline COPD & 2.22 & $1.1-4.48$ & 0.026 \\
\hline Thyroid diseases & 1.59 & $1.07-2.35$ & 0.021 \\
\hline Cancer & 4.66 & $3.01-7.21$ & $<0.001$ \\
\hline Chronic liver diseases & 7.22 & $3.54-14.72$ & $<0.001$ \\
\hline \multicolumn{4}{|l|}{ Drugs } \\
\hline Anticoagulants (VKA, DOACs) & 3.58 & $2.28-5.61$ & $<0.001$ \\
\hline Antiplatelet agents (Aspirin) & 3.38 & $2.4-4.77$ & $<0.001$ \\
\hline \multicolumn{4}{|l|}{ Number of comorbidities } \\
\hline 1 & 2.14 & $1.26-3.65$ & 0.005 \\
\hline 2 & 4.38 & $2.56-7.49$ & $<0.001$ \\
\hline 3 & 10.92 & $6.13-19.47$ & $<0.001$ \\
\hline 4 & 13.22 & $5.95-29.37$ & $<0.001$ \\
\hline 5 & 14.04 & $2.69-73.33$ & 0.002 \\
\hline Hospitalization & 1.46 & $1.28-1.67$ & $<0.001$ \\
\hline
\end{tabular}

$O R$, odds ratio; $C I$, confidence interval; $C O P D$, chronic obstructive pulmonary disease; $V K A$, vitamin $\mathrm{K}$ antagonists; $D O A C s$ direct oral anticoagulants

$P<0.05$ - statistically significant

complex pathogenesis of anemia occurs in chronic kidney disease, alcoholism, endocrine disorders, and chemo-/radiotherapy-associated anemia.

In our study, patients aged 60 or more with anemia were more frequently hospitalized than those without anemia. Thus, the patients with anemia were older, which could have had an impact on the number of comorbidities and need for hospitalization. However, regardless of age, all patients with anemia more often had significantly chronic liver disease, heart failure, and chronic kidney disease.

Our observation is in line with other studies, which also reported that patients with anemia were older than those without anemia [5, 43], and this is consistent with an increased incidence of anemia with age. The association of anemia with hospitalizations has also been demonstrated in other studies $[5,43,45]$. Based on a 4-year observation of the Established
Table 6 Multivariate regression analysis for occurrence of anemia

\begin{tabular}{llll}
\hline Parameter & OR & $95 \% \mathrm{CI}$ & P value \\
\hline $\begin{array}{lll}\text { Age, years } \\
70-79\end{array}$ & 1.35 & $0.73-2.52$ & 0.338 \\
$\geq 80$ & 2.29 & $1.19-4.42$ & 0.013 \\
Number of comorbidities & & & \\
1 & 1.42 & $0.57-3.53$ & 0.454 \\
2 & 2.85 & $1.12-7.30$ & 0.029 \\
3 & 6.28 & $2.22-17.76$ & 0.001 \\
4 & 4.64 & $1.26-17.01$ & 0.021 \\
5 & 1.37 & $0.13-14.52$ & 0.793 \\
Hospitalization & 1.34 & $1.13-1.58$ & 0.001 \\
\hline
\end{tabular}

$O R$, odds ratio; $C I$, confidence interval

$P<0.05$ - statistically significant

Populations for Epidemiologic Studies of the Elderly (EPESE), it has been shown that anemia is related to a significant increase in hospitalizations and prolonged hospital stays [5]. The occurrence of hospital-acquired anemia (HAA) may also be associated with invasive medical procedures, excessive testing, and modern therapy, especially using thrombolytic, antithrombotic, and antiplatelet agents. Depending on the study population and reasons for hospitalization (e.g., acute coronary syndrome, kidney disease), it is estimated that the prevalence of HAA varies from 25 to $74 \%$ [46]. In the course of hospitalization, patients with anemia were more likely to undergo medical procedures such as coronary angiography and PTCA. The relationship between anemia and these

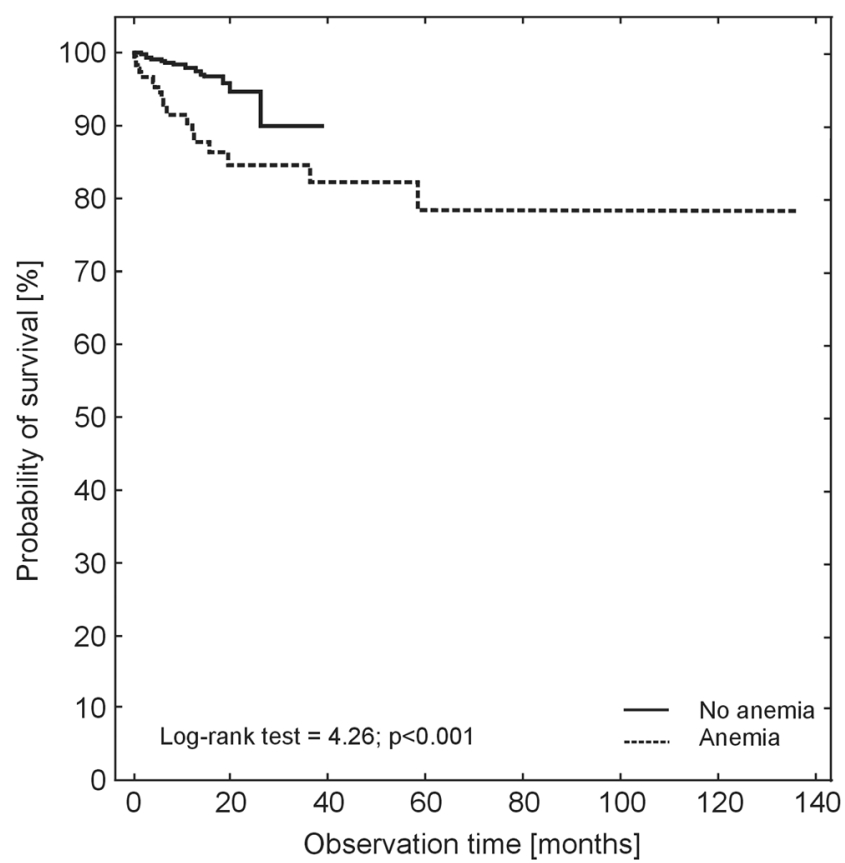

Fig. 3 Cumulative survival probability of the studied patients aged $\geq$ 60 years with or without anemia 
Table 7 Univariate analyses determining factors affecting mortality in the population aged 60 or over

\begin{tabular}{|c|c|c|c|}
\hline Parameter/variables & $\mathrm{HR}$ & $95 \% \mathrm{CI}$ & $P$ value \\
\hline Male gender & 1.03 & $0.53-2.01$ & 0.921 \\
\hline \multicolumn{4}{|l|}{ Age, years } \\
\hline $70-79$ & 1.28 & $0.46-3.61$ & 0.635 \\
\hline$\geq 80$ & 7.60 & $3.47-16.65$ & $<0.001$ \\
\hline \multicolumn{4}{|l|}{ eGFR vs. $>90 \mathrm{ml} / \mathrm{min} / 1.73 \mathrm{~m}^{2}$} \\
\hline$<15$ & $1.99 \mathrm{E}-19$ & - & - \\
\hline $15-29$ & $1.08 \mathrm{E}-17$ & - & - \\
\hline $30-59$ & 0.88 & $0.29-2.65$ & 0.811 \\
\hline $60-89$ & 0.95 & $0.42-2.18$ & 0.908 \\
\hline Diabetes & 0.60 & $0.25-1.44$ & 0.252 \\
\hline Diabetes with complications & 0.85 & $0.33-2.20$ & 0.740 \\
\hline Heart failure & 5.01 & $2.56-9.8$ & $<0.001$ \\
\hline Cancer & 4.82 & $2.44-9.54$ & $<0.001$ \\
\hline Anemia & 4.32 & $2.18-8.56$ & $<0.001$ \\
\hline Acute coronary syndrome & 1.75 & $0.76-4.03$ & 0.184 \\
\hline Stroke & 1.28 & $0.39-4.20$ & 0.679 \\
\hline \multicolumn{4}{|l|}{ Types of anemia } \\
\hline Anemia of chronic disease & 1.54 & $0.63-3.77$ & 0.350 \\
\hline Unexplained anemia & 0.87 & $0.32-2.39$ & 0.785 \\
\hline Iron deficiency anemia & 0.28 & $0.04-2.06$ & 0.209 \\
\hline Vitamin B12 deficiency anemia & 0.82 & $0.19-3.57$ & 0.795 \\
\hline Folate deficiency anemia & $6.14 \mathrm{E}-16$ & - & 1.000 \\
\hline Chemo- and/or radiotherapy-induced anemia & 1.89 & $0.55-6.46$ & 0.312 \\
\hline Hemorrhagic anemia & 1.14 & $0.15-8.53$ & 0.901 \\
\hline Renal insufficiency anemia & $6.21 \mathrm{E}-16$ & - & 1.000 \\
\hline Other types of anemia & $2.18 \mathrm{E}-16$ & - & 1.000 \\
\hline
\end{tabular}

$H R$, hazard ratio; $C I$, confidence interval

$P<0.05$ - statistically significant

procedures is complex. The procedures themselves promote the occurrence of anemia, as was observed in one out of every three patients with acute coronary syndrome, 1 month after discharge from hospital [47]. Possibly, one of the reasons that the patients required hospitalization and the implementation of these procedures was the presence of anemia and its impact on the cardiovascular system. It appears that the problem of hospital-acquired anemia in elderly patients has thus far been insufficiently observed.

In our study, the relation between comorbidities, number of hospitalizations, and anemia has been confirmed in the logistic regression analyses. In the univariate analysis, patients with a coexistence of two to five comorbidities have a nearly 2 to 14 fold increased risk of anemia development. In the multivariate logistic regression model, factors increasing the risk of anemia were age $\geq 80$ years, the number of comorbidities (from two to four diseases) and hospitalizations. Due to the small number of patients with five concomitant diseases and anemia, we failed to show any relationship between the coexistence of five diseases and anemia development. To our knowledge, only a few studies have investigated comorbidities and hospitalizations as factors for anemia development, and no study has highlighted the increased risk of anemia with the number of comorbidities and the number of hospitalizations. In a multivariate logistic regression analysis, only Penninx et al. reported the following factors significantly associated with the higher prevalence of anemia: older age, black race, cancer, kidney disease, hospitalization during the previous year, and BMI [5]. There seems to be reciprocal feedback: the presence of comorbidities or the treatment used promotes the onset of anemia [48-53]. Anemia exacerbates the course of a number of diseases $[51,54-56]$ and

Table 8 Multivariate analysis determining factors affecting mortality in the population aged 60 or over

\begin{tabular}{llll}
\hline Parameter & HR & $95 \%$ CI & $P$ value \\
\hline Anemia & 3.33 & $1.43-7.74$ & 0.005 \\
Heart failure & 2.94 & $1.33-6.51$ & 0.008 \\
Cancer & 3.31 & $1.47-7.49$ & 0.004 \\
\hline
\end{tabular}

$H R$, hazard ratio; $C I$ confidence interval

$P<0.05$ — statistically significant 
may be one of the factors that contribute to the need to perform certain medical procedures (e.g., coronary angiography) or hospitalization (especially due to heart failure) [42, 54, 57], and both procedures and hospitalizations may be conducive to the development of anemia [47, 58].

In the present study, anemia at age $\geq 60$ years had a negative impact on survival, and was, in addition to heart failure and cancer, one of the most important risk factors for death. This is in agreement with data from previous studies that have also shown the negative effect of anemia on survival [5, 43, 45, 59]. Similarly, Zakai et al. have shown that anemia is an important risk factor for mortality, not only in relation to cardiovascular disease, heart failure, and cancer, but also diabetes [59].

The present study was conducted on a large, well-defined group of patients in advanced age and included analysis of many factors affecting their health condition. The conclusion can be drawn that anemia is common among the studied population and its prevalence increases with age. The presence of anemia increases the risk of death, and additionally, there is an association between anemia and comorbities and hospitalizations. Based on our results, it is possible to identify the group of elderly patients at high risk of the development of anemia, which is made up of people aged 80 and over, with two or more comorbidities, and those who require hospitalization. Identification of the risk group may provide the basis for recommendations for more frequent blood morphology testing in the population at risk of anemia development.

For two decades, there has been no change in the situation of elderly patients with unexplained anemia and therefore no effective treatment is possible. The diagnosis of unexplained anemia in nearly one third of patients indicates, on the one hand, the need for a more in-depth diagnosis, and on the other hand, further research to understand the causes of anemia in this age group.

\section{Compliance with ethical standards}

Conflict of interest The authors declare that they have no conflict of interest.

Open Access This article is distributed under the terms of the Creative Commons Attribution 4.0 International License (http:// creativecommons.org/licenses/by/4.0/), which permits unrestricted use, distribution, and reproduction in any medium, provided you give appropriate credit to the original author(s) and the source, provide a link to the Creative Commons license, and indicate if changes were made.

\section{References}

1. Department of Economic, and social affairs (2015) United Nations Department of economic and social affairs/population division 5 world population prospects: The 2015 ReviSion

2. Barnett K, Mercer SW, Norbury M, Watt G, Wyke S, Guthrie B (2012) Epidemiology of multimorbidity and implications for health care, research, and medical education: a cross-sectional study. Lancet Lond Engl 380:37-43

3. Hall MJ, DeFrances CJ, Williams SN et al (2010) National hospital discharge survey: 2007 summary. Natl Health Stat Rep 1-20:24

4. Hovstadius B, Hovstadius K, Åstrand B, Petersson G (2010) Increasing polypharmacy - an individual-based study of the Swedish population 2005-2008. BMC Clin Pharmacol 10:16. https://doi.org/10.1186/1472-6904-10-16

5. Penninx BWJH, Pahor M, Woodman RC, Guralnik JM (2006) Anemia in old age is associated with increased mortality and hospitalization. J Gerontol A Biol Sci Med Sci 61:474-479

6. Corona LP, de Oliveira Duarte YA, Lebrão ML (2014) Prevalence of anemia and associated factors in older adults: evidence from the SABE study. Rev Saude Publica 48:723-431

7. Loutradis C, Skodra A, Georgianos P, Tolika P, Alexandrou D, Avdelidou A, Sarafidis PA (2016) Diabetes mellitus increases the prevalence of anemia in patients with chronic kidney disease: a nested case-control study. World J Nephrol 5:358-366. https://doi. org/10.5527/wjn.v5.i4.358

8. Blanc B, Finch C, Hallberg L, Herbert V (1968) Nutritional anaemias. Report of a WHO scientific group. World Health Organ. Tech Rep Ser 405:5-37

9. Groopman JE, Itri LM (1999) Chemotherapy-induced anemia in adults: incidence and treatment. J Natl Cancer Inst 91:1616-1634

10. Guralnik JM, Eisenstaedt RS, Ferrucci L, Klein HG, Woodman RC (2004) Prevalence of anemia in persons 65 years and older in the United States: evidence for a high rate of unexplained anemia. Blood 104:2263-2268

11. Ble A, Fink JC, Woodman RC, Klausner MA, Windham BG, Guralnik JM, Ferrucci L (2005) Renal function, erythropoietin, and anemia of older persons: the InCHIANTI study. Arch Intern Med 165:2222-2227. https://doi.org/10.1001/archinte.165.19.2222

12. Price EA, Mehra R, Holmes TH, Schrier SL (2011) Anemia in older persons: etiology and evaluation. Blood Cells Mol Dis 46:159-165

13. Gowanlock Z, Sriram S, Martin A, Xenocostas A, Lazo-Langner A (2016) Erythropoietin levels in elderly patients with Anemia of unknown etiology. PLoS One 11:e0157279. https://doi.org/10. 1371/journal.pone.0157279

14. Mercadal L, Metzger M, Casadevall N, Haymann JP, Karras A, Boffa JJ, Flamant M, Vrtovsnik F, Stengel B, Froissart M, on behalf of the NephroTest Study Group (2012) Timing and determinants of erythropoietin deficiency in chronic kidney disease. Clin J Am Soc Nephrol 7:35-42. https://doi.org/10.2215/CJN.04690511

15. McMurray JJV, Adamopoulos S, Anker SD, Auricchio A, Böhm M, Dickstein K, Falk V, Filippatos G, Fonseca C, Gomez-Sanchez MA, Jaarsma T, Køber L, Lip GY, Maggioni AP, Parkhomenko A, Pieske BM, Popescu BA, Rønnevik PK, Rutten FH, Schwitter J, Seferovic P, Stepinska J, Trindade PT, Voors AA, Zannad F, Zeiher A, Task Force for the Diagnosis and Treatment of Acute and Chronic Heart Failure 2012 of the European Society of Cardiology, Bax JJ, Baumgartner H, Ceconi C, Dean V, Deaton C, Fagard R, Funck-Brentano C, Hasdai D, Hoes A, Kirchhof P, Knuuti J, Kolh P, McDonagh T, Moulin C, Popescu BA, Reiner Z, Sechtem U, Sirnes PA, Tendera M, Torbicki A, Vahanian A, Windecker S, McDonagh T, Sechtem U, Bonet LA, Avraamides P, Ben Lamin HA, Brignole M, Coca A, Cowburn P, Dargie H, Elliott P, Flachskampf FA, Guida GF, Hardman S, Iung B, Merkely B, Mueller C, Nanas JN, Nielsen OW, Orn S, Parissis JT, Ponikowski P, ESC Committee for Practice Guidelines (2012) ESC guidelines for the diagnosis and treatment of acute and chronic heart failure 2012: the task force for the diagnosis and treatment of acute and chronic heart failure 2012 of the European Society of Cardiology. Developed in collaboration with the heart failure association (HFA) of the ESC. Eur J Heart Fail 14:803-869

16. Mancia G, Fagard R, Narkiewicz K, Redón J, Zanchetti A, Böhm M, Christiaens T, Cifkova R, de Backer G, Dominiczak A, 
Galderisi M, Grobbee DE, Jaarsma T, Kirchhof P, Kjeldsen SE, Laurent S, Manolis AJ, Nilsson PM, Ruilope LM, Schmieder RE, Sirnes PA, Sleight P, Viigimaa M, Waeber B, Zannad F, Task Force Members (2013) $2013 \mathrm{ESH} / \mathrm{ESC}$ guidelines for the management of arterial hypertension: the task force for the management of arterial hypertension of the European Society of Hypertension (ESH) and of the European Society of Cardiology (ESC). J Hypertens 31: $1281-1357$

17. Authors/Task Force Members, Rydén L, Grant PJ et al (2013) ESC guidelines on diabetes, pre-diabetes, and cardiovascular diseases developed in collaboration with the EASD: the task force on diabetes, pre-diabetes, and cardiovascular diseases of the European Society of Cardiology (ESC) and developed in collaboration with the European Association for the Study of diabetes (EASD). Eur Heart J 34:3035-3087

18. Stevens PE, Levin A, Kidney disease: improving global outcomes chronic kidney disease guideline development work group members (2013) Evaluation and management of chronic kidney disease: synopsis of the kidney disease: improving global outcomes 2012 clinical practice guideline. Ann Intern Med 158:825-830

19. European Association for the Study of the Liver (2012) EASL clinical practice guidelines: management of chronic hepatitis B virus infection. J Hepatol 57:167-185

20. Vestbo J, Hurd SS, Agustí AG, Jones PW, Vogelmeier C, Anzueto A, Barnes PJ, Fabbri LM, Martinez FJ, Nishimura M, Stockley RA, Sin DD, Rodriguez-Roisin R (2013) Global strategy for the diagnosis, management, and prevention of chronic obstructive pulmonary disease: GOLD executive summary. Am J Respir Crit Care Med 187:347-365

21. Boulet L-P, FitzGerald JM, Levy ML et al (2012) A guide to the translation of the global initiative for asthma (GINA) strategy into improved care. Eur Respir J 39:1220-1229

22. Edge SB, Compton CC (2010) The American joint committee on Cancer: the 7th edition of the AJCC cancer staging manual and the future of TNM. Ann Surg Oncol 17:1471-1474

23. Aletaha D, Neogi T, Silman AJ, Funovits J, Felson DT, Bingham CO III, Birnbaum NS, Burmester GR, Bykerk VP, Cohen MD, Combe B, Costenbader KH, Dougados M, Emery P, Ferraccioli G, Hazes JMW, Hobbs K, Huizinga TWJ, Kavanaugh A, Kay J, Kvien TK, Laing T, Mease P, Ménard HA, Moreland LW, Naden RL, Pincus T, Smolen JS, Stanislawska-Biernat E, Symmons D, Tak PP, Upchurch KS, Vencovský J, Wolfe F, Hawker G (2010) 2010 rheumatoid arthritis classification criteria: an American College of Rheumatology/European league against rheumatism collaborative initiative. Arthritis Rheum 62:2569-2581. https:// doi.org/10.1002/art.27584

24. Runyon BA, AASLD (2013) Introduction to the revised American Association for the Study of Liver Diseases practice guideline management of adult patients with ascites due to cirrhosis 2012 . Hepatology 57:1651-1653

25. News | ESMO Clinical Practice Guidelines | ESMO. http://www. esmo.org/Guidelines/Guidelines-News

26. Ferrucci L, Semba RD, Guralnik JM, Ershler WB, Bandinelli S, Patel KV, Sun K, Woodman RC, Andrews NC, Cotter RJ, Ganz T, Nemeth E, Longo DL (2010) Proinflammatory state, hepcidin, and anemia in older persons. Blood 115:3810-3816

27. Tettamanti M, Lucca U, Gandini F, Recchia A, Mosconi P, Apolone G, Nobili A, Tallone MV, Detoma P, Giacomin A, Clerico M, Tempia P, Savoia L, Fasolo G, Ponchio L, Della Porta MG, Riva E (2010) Prevalence, incidence and types of mild anemia in the elderly: the "health and Anemia" population-based study. Haematologica 95:1849-1856

28. Wieczorowska-Tobis K, Czepulis N, Mossakowska M et al (2012) Występowanie niedokrwistości w populacji starszych Polaków. In: Mossakowska M, Więcek A, Błędowski P (eds) Aspekty medyczne, psychologiczne, socjologiczne i ekonomiczne starzenia się ludzi w Polsce. Termedia Wydawnictwa Medyczne, Poznań, pp 251-264

29. Choi CW, Lee J, Park KH, Yoon SY, Choi IK, Oh SC, Seo JH, Kim BS, Shin SW, Kim YH, Kim JS (2004) Prevalence and characteristics of anemia in the elderly: cross-sectional study of three urban Korean population samples. Am J Hematol 77:26-30

30. Bach V, Schruckmayer G, Sam I, Kemmler G, Stauder R (2014) Prevalence and possible causes of anemia in the elderly: a crosssectional analysis of a large European university hospital cohort. Clin Interv Aging 9:1187-1196

31. Beghé C, Wilson A, Ershler WB (2004) Prevalence and outcomes of anemia in geriatrics: a systematic review of the literature. Am J Med 116(Suppl 7A):3S-10S

32. Artz AS, Thirman MJ (2011) Unexplained anemia predominates despite an intensive evaluation in a racially diverse cohort of older adults from a referral anemia clinic. J Gerontol A Biol Sci Med Sci 66:925-932

33. Ferrucci L, Guralnik JM, Bandinelli S, Semba RD, Lauretani F, Corsi A, Ruggiero C, Ershler WB, Longo DL (2007) Unexplained anaemia in older persons is characterised by low erythropoietin and low levels of pro-inflammatory markers. Br J Haematol 136:849-855

34. Anía BJ, Suman VJ, Fairbanks VF, Rademacher DM, III LJM (1997) Incidence of anemia in older people: an epidemiologic study in a well defined population. J Am Geriatr Soc 45:825-831

35. Joosten E, Pelemans W, Hiele M, Noyen J, Verhaeghe R, Boogaerts MA (1992) Prevalence and causes of anaemia in a geriatric hospitalized population. Gerontology 38:111-117

36. Malcovati L, Gallì A, Travaglino E, Ambaglio I, Rizzo E, Molteni E, Elena C, Ferretti VV, Catricalà S, Bono E, Todisco G, Bianchessi A, Rumi E, Zibellini S, Pietra D, Boveri E, Camaschella C, Toniolo D, Papaemmanuil E, Ogawa S, Cazzola M (2017) Clinical significance of somatic mutation in unexplained blood cytopenia. Blood 129:3371-3378. https://doi.org/10.1182/blood-2017-01-763425

37. Caro JJ, Salas M, Ward A, Goss G (2001) Anemia as an independent prognostic factor for survival in patients with cancer: a systemic, quantitative review. Cancer 91:2214-2221

38. Crawford J, Cella D, Cleeland CS, Cremieux PY, Demetri GD, Sarokhan BJ, Slavin MB, Glaspy JA (2002) Relationship between changes in hemoglobin level and quality of life during chemotherapy in anemic cancer patients receiving epoetin alfa therapy. Cancer 95:888-895

39. Ferrucci L, Balducci L (2008) Anemia of aging: the role of chronic inflammation and cancer. Semin Hematol 45:242-249

40. La Vecchia C, Bosetti C, Lucchini F et al (2010) Cancer mortality in Europe, 2000-2004, and an overview of trends since 1975. Ann Oncol Off J Eur Soc Med Oncol 21:1323-1360. https://doi.org/10. 1093/annonc/mdp530

41. Maggio M, Guralnik JM, Longo DL, Ferrucci L (2006) Interleukin6 in aging and chronic disease: a magnificent pathway. J Gerontol A Biol Sci Med Sci 61:575-584

42. Lawler PR, Filion KB, Dourian T, Atallah R, Garfinkle M, Eisenberg MJ (2013) Anemia and mortality in acute coronary syndromes: a systematic review and meta-analysis. Am Heart J 165: 143-153.e5

43. Riva E, Tettamanti M, Mosconi P, Apolone G, Gandini F, Nobili A, Tallone MV, Detoma P, Giacomin A, Clerico M, Tempia P, Guala A, Fasolo G, Lucca U (2009) Association of mild anemia with hospitalization and mortality in the elderly: the Health and Anemia population-based study. Haematologica 94:22-28

44. Gonzalez-Casas R, Jones EA, Moreno-Otero R (2009) Spectrum of anemia associated with chronic liver disease. World J Gastroenterol $15: 4653-4658$

45. Culleton BF, Manns BJ, Zhang J, Tonelli M, Klarenbach S, Hemmelgarn BR (2006) Impact of anemia on hospitalization and mortality in older adults. Blood 107:3841-3846 
46. Kurniali PC, Curry S, Brennan KW et al (2014) A retrospective study investigating the incidence and predisposing factors of hospital-acquired anemia. Anemia 2014:634582

47. Salisbury AC, Kosiborod M, Amin AP, Reid KJ, Alexander KP, Spertus JA, Masoudi FA (2011) Recovery from hospital-acquired anemia after acute myocardial infarction and effect on outcomes. Am J Cardiol 108:949-954

48. O'Meara E, Rouleau JL, White M et al (2014) Heart failure with anemia: novel findings on the roles of renal disease, interleukins, and specific left ventricular remodeling processes. Circ Heart Fail 7: 773-781. https://doi.org/10.1161/CIRCHEARTFAILURE.114. 001100

49. Portillo K, Martinez-Rivera C, Ruiz-Manzano J (2013) Anaemia in chronic obstructive pulmonary disease. Does it really matter? Int J Clin Pract 67:558-565. https://doi.org/10.1111/ijcp.12125

50. Stein J, Connor S, Virgin G, Ong DEH, Pereyra L (2016) Anemia and iron deficiency in gastrointestinal and liver conditions. World $\mathrm{J}$ Gastroenterol 22:7908-7925. https://doi.org/10.3748/wjg.v22.i35. 7908

51. Silverberg DS, Wexler D, Iaina A, Schwartz D (2006) The interaction between heart failure and other heart diseases, renal failure, and anemia. Semin Nephrol 26:296-306. https://doi.org/10.1016/j. semnephrol.2006.05.006

52. Gaskell H, Derry S, Moore RA (2010) Is there an association between low dose aspirin and anemia (without overt bleeding)?: narrative review. BMC Geriatr 10:71

53. Crowther MA, Warkentin TE (2008) Bleeding risk and the management of bleeding complications in patients undergoing anticoagulant therapy: focus on new anticoagulant agents. Blood 111: 4871-4879. https://doi.org/10.1182/blood-2007-10-120543
54. Young JB, Abraham WT, Albert NM, Gattis Stough W, Gheorghiade M, Greenberg BH, O'Connor CM, She L, Sun JL, Yancy CW, Fonarow GC, OPTIMIZE-HF Investigators and Coordinators (2008) Relation of low hemoglobin and anemia to morbidity and mortality in patients hospitalized with heart failure (insight from the OPTIMIZE-HF registry). Am J Cardiol 101:223230. https://doi.org/10.1016/j.amjcard.2007.07.067

55. Toft-Petersen AP, Torp-Pedersen C, Weinreich UM, Rasmussen BS (2016) Association between hemoglobin and prognosis in patients admitted to hospital for COPD. Int J Chron Obstruct Pulmon Dis 11:2813-2820. https://doi.org/10.2147/COPD.S116269

56. Ito $\mathrm{H}$, Takeuchi $\mathrm{Y}$, Ishida $\mathrm{H}$, Otawa $\mathrm{A}$, Shibayama A, Antoku S, Abe M, Mifune M, Togane M (2010) Mild anemia is frequent and associated with micro- and macroangiopathies in patients with type 2 diabetes mellitus. J Diabetes Investig 1:273-278. https://doi.org/ 10.1111/j.2040-1124.2010.00060.x

57. Yazji K, Abdul F, Elangovan S, Ul Haq MZ, Ossei-Gerning N, Morris K, Anderson R, Kinnaird T (2017) Baseline anemia in patients undergoing percutaneous coronary intervention after an acute coronary syndrome-a paradox of high bleeding risk, high ischemic risk, and complex coronary disease. J Interv Cardiol 30:491-499. https://doi.org/10.1111/joic. 12406

58. Makam AN, Nguyen OK, Clark C, Halm EA (2017) Incidence, predictors, and outcomes of hospital-acquired Anemia. J Hosp Med 12:317-322. https://doi.org/10.12788/jhm.2712

59. Zakai NA, Katz R, Hirsch C, Shlipak MG, Chaves PHM, Newman AB, Cushman M (2005) A prospective study of anemia status, hemoglobin concentration, and mortality in an elderly cohort: the cardiovascular health study. Arch Intern Med 165:2214-2220 